від 17 січня 2002 р. № 2984 // Офіційний вісник України. - 2002. - № 8. - С. 3-43. 5. Національна доктрина розвитку освіти // Офіційний вісник України. - 2002. - № 16. - С. 2 14. 6. Тарасенко Г. С. Дивосвіт. Технологія естетико-екологічного виховання / Г. С. Тарасенко. - [2-ге вид., із змін.]. - Київ: Рута, 2000. - 208 с. 7. Тарасенко Г. С. Взаємозв'язок естетичної та екологічної підготовки вчителя в системі професійної освіти: [монографія] / Г. С. Тарасенко. - Черкаси: «Вертикаль», ПП Кандич С. Г., 2006. - 308 с.

\title{
РЕАЛІЗАЦІЯ КОМПЕТЕНТНІСНОГО ПЦДХОДУ ПІД ЧАС ФОРМУВАННЯ В МОЛОДШИХ ШКОЛЯРІВ НАВИЧОК МОВНИХ РОЗБОРІВ
}

Жигора І. В. Реалізація компетентнісного підходу під час формування в молодших школярів навичок мовних розборів.

У статті проаналізовано поняття компетентнісного підходу під час формування в молодших школярів навичок мовних розборів. Основну увагу зосереджено на мовному розборі як показнику обізнаності (компетентності) учнів початкових класів у певному мовному матеріалі. Мовний розбір досліджується як засіб узагальнення та систематизації набутих знань учнів з української мови, що сприяє роботі над формуванням загальномовної компетентності учнів початкових класів.

Ключові слова: компетентнісний підхід, мовна компетентність, мовний розбір, мовний аналіз.

Жигора И. В. Реализация компетентностного подхода в процессе формирования у младших школьников навыков языковых разборов.

В статье проанализировано понятие компетентностного подхода в процессе формирования у младших школьников навыков языковых разборов. Основное внимание уделено языковому разбору как показателю компетентности учеников начальных классов в конкретном языковом материале. Языковой разбор рассматривается как способ обобщения и систематизации полученных знаний учениками по украинскому языку, что способствует работе над формированием общеязыковой компетентности учеников младших классов.

Ключевые слова: компетентностный подход, языковая компетентность, языковой разбор, языковой анализ.

Zhigora I. V. The implementation of competence-based approach in the process of formation of primary pupils' linguistic analysis skills.

In the article the concept of competence-based in the process of formation of primary pupils' linguistic analysis skills has been analyzed. The main focus was made on the linguistic analysis as a level of primary school pupils' competence in the certain linguistic material. Linguistic analysis is studied as a means of generalization and systematization of acquired knowledgeof Ukrainian language, which contributes to the formation of general linguistic competence of primary school pupils.

Key words: competence-based approach, linguistic competence, linguistic parsing, linguistic analysis. 
Слово «компетентність» має єдину, загальноприйняту дефініцію. Згідно з Великим тлумачним словником компетентний - який має достатні знання в будь-якій небудь галузі, який із чим-небудь добре обізнаний, тямущий. Відповідно, «компетентнісність» як властивість за значенням «компетентний» вказує на поінформованість, обізнаність [2, с. 560].

Отже, обізнаною, компетентнісно зорієнтованою особистістю можна назвати індивідуальність, яка на достатньому рівні оволоділа найважливішими життєвими компетенціями і здатна розв'язувати проблеми, зокрема, креативно та досягати професійного успіху $[9$, с. 3$]$.

Нині педагоги виокремлюють різні групи компетентностей що певною мірою варіюються (соціальна, полікультурна, комунікативна, інформаційна, саморозвитку й самоосвіти, продуктивної творчої діяльності). Кожна 3 них передбачає можливості продуктивного навчання. Так, комунікативна компетентність - це уміння спілкуватися усно й письмово рідною мовою, передбачає такі можливості продуктивного навчання: обговорення проблем; формування власного погляду на мовні явища; уміння доводити власну позицію; розвиток культури мовлення; уміння презентувати свій продукт; можливість для безпосереднього спілкування; адекватне ставлення до критики; стимулювання критичного ставлення до себе; уміння адаптуватися в мовному середовищі.

Відповідно до вимог нового Державного стандарту зміст початкової освіти охоплює ключові компетентності (уміння вчитися, інформаційно-комунікативну, загальнокультурну, здоров'язбережувальну, громадянську, соціальну), що формуються на міжпредметній основі i $є$ інтегрованим результатом предметних та міжпредметних компетентностей [7, с. 5].

У навчальних програмах з кожного предмета визначено державні вимоги до рівня загальноосвітньої підготовки учнів, що враховують саме зміст і структуру предметних компетентностей. Щодо рідної мови, то учні початкових класів повинні розпізнавати мовні одиниці, мовні явища, знати і розуміти їх, застосовувати, зіставляти, оцінювати тощо.

Навчання учнів рідної мови передбачає насамперед розвиток мовлення і чуття слова, оволодіння основами норм і тонкощами української мови. Українська мова як навчальна дисципліна посідає одне 3 найважливіших місць у підготовці фахівця для будь-якої діяльності.

Завдання предмета - забезпечити теоретичну і практичну підготовку учнів: дати основні відомості про мову як суспільне та історичне явище, про структуру і закономірності iï розвитку, а також допомогти оволодіти нормами сучасної української літературної мови, сформувати міцні практичні навички мовного аналізу, грамотного письма і високої культури мовлення, бережного ставлення до слова.

Відомо, що мовлення кожного - це вираження нашої особистості, наш інтелектуальний i духовний портрет. Тому, здобуваючи освіту, кожен учень повинен усвідомити, що з усіх наук йому найперше слід опанувати мову - знаряддя мисленнєвої i мовної діяльності.

Для учня мова - і засіб спілкування, і засіб пізнання навколишнього світу, і засіб оволодіння основами наук у школі, і об'єкт вивчення. Досконало знати мову означає вправно послуговуватися різними стилями мовлення, уміти добирати до кожного стилю й жанру відповідну лексику, відчувати дієвий вплив на комунікацію окремих лексичних одиниць та мовних фігур.

У процесі вивчення всього курсу української мови принагідно розглядаються питання стилістики, що сприяє збагаченню мови учнів, привчає їх бережно ставитися до слова, дбати про культуру свого мовлення і мовлення своїх однокласників. Тому на вчителя початкових 
класів покладено велику відповідальність, адже від нього залежить, які основи з української мови він дасть молодшим школярам, оскільки початкова школа є «пропедевтичною» до старших класів.

Предметом нашої статті $є$ мовний розбір як показник, складник обізнаності (компетентності) учнів початкових класів у певному мовному матеріалі.

Mema cmammi- проаналізувати поняття компетентнісного підходу під час формування у молодших школярів навичок мовних розборів.

Залежно від того, наскільки вчитель методично правильно подасть учням матеріал, залежить рівень мовної компетентності кожного школяра.

Теоретичний і практичний курси української мови учням буває нелегко опанувати через те, що в сучасному мовознавстві $\epsilon$ різні школи i напрями, виробилися різні класифікації мовних явищ, різні погляди на розбір тих чи тих мовних одиниць. Завдання вчителя полягає в тому, щоб полегшити учням засвоєння основних теоретичних відомостей 3 української мови та сформувати у них певні мовні навички, зокрема, мовних розборів, подавши матеріал адаптовано, доступно відповідно до шкільної програми.

3-поміж різних методів та прийомів навчання української мови мовний розбір посідає особливе місце. Це ефективний засіб узагальнення та систематизації знань, що сприяє свідомому засвоєнню учнями початкової школи програмового матеріалу, формуванню в них мовних та мовленнєвих умінь і навичок.

Як термін у теорії і практиці навчання мови з'явився завдяки I. Чередниченку, який виокремлював метод аналізу мовного матеріалу і граматичний розбір, що, на його думку, є різновидом мовного аналізу, його складником [10]. У спеціальній літературі дотепер відсутнє цілісне, системне визначення поняття «мовний розбір», що багатьма вчителями вживається як синонім до поняття «мовний аналіз». Питання мовного аналізу, розбору розглядаються дослідниками неоднозначно, немає єдиного, загальноприйнятого визначення, яке б універсально і всебічно характеризувало ці поняття.

У Словнику лінгвістичних термінів зазначається: «мовний розбір - це аналіз мовних явищ, виявлення і характеристика в певній послідовності їхніх ознак, властивостей. Мовний розбір - це один із прийомів вивчення української і російської мов. Його застосування допомагає краще усвідомити виучувані мовні явища, виробити навички застосовувати теоретичні значення на практиці, здійснювати закріплення, систематизацію й узагальнення матеріалу, а також проводити контроль і самоконтроль. Розбір за обсягом проведення може бути повний i частковий, за способом виконання - усний і письмовий, за змістомфонетичний, лексичний, морфемний, словотворчий, етимологічний, морфологічний, синтаксичний, орфографічний, пунктуаційний (у початковій школі переважно практикують фонетичний: звуко-складовий, звуко-буквений, орфографічний, морфемний, морфологічний слів як частин мови, синтаксичний). Будь-який розбір необхідно проводити, зберігаючи чітку послідовність у визначенні й характеристиці ознак аналізованого явища. Міра докладності кожного з видів розбору визначається метою, завданням та умовами його проведення (у школі, ВН3, на тому чи тому етапі навчання) ...» [3, с. 241].

Питання мовного аналізу та розбору цікавило науковців, учителів ще у 50-70 p.p., дискутивними вони є і дотепер. Певні аспекти мовного розбору висвітлили у своїх працях такі провідні педагоги і методисти, як С. Чавдаров, В. Масальський, Є. Дмитровський, А. Медушевський, I. Чередниченко, Г. Передрій, С. Дорошенко, М. Вашуленко та інші, які досліджували позитивне у мовному розборі та звертали увагу на недоліки в практиці його проведення $[1 ; 4 ; 6 ; 10]$. 
Досліджуючи сутність поняття «мовний розбір», М. Чабайовська зазначає, що в науковців немає єдиної думки щодо цього питання [10, с. 3]. Так, Є. Дмитровський визначає мовний розбір як метод навчання, такі педагоги, як О. Біляєв В. Мельничайко, С. Дорошенко, Г. Передрій [4; 5; 8] - як прийом, вправу. В. Мельничайко слушно зауважує, що у складній системі мови «...функціонують виражальні засоби різних рівнів, на кожному 3 яких є свої мовні одиниці (фонема, морфема, слово, форма слова, словосполучення, речення, складне синтаксичне ціле, текст). Цим визначаються і види мовного розбору - фонетичний, морфемний, лексичний, морфологічний та синтаксичний, що охоплює одиниці всіх рівнів синтаксису. Крім цього, практичний аспект опрацювання мовного матеріалу зумовлює необхідність орфографічного, пунктуаційного та стилістичного аналізу, елементи яких знаходять застосування у лексичному, морфологічному та стилістичному видах розбору» [5, с. 3].

Усі вони дотримуються думки, що навчання мови передбачає комплексне вивчення мовного матеріалу, що зумовлює широке застосування різних видів мовного розбору, кожен iз яких повинен взаємодіяти 3 іншим і спрямовуватися на комплексну характеристику мовних явищ. Г. Передрій відзначає, що мовний розбір, за яким слово або речення аналізується в кількох аспектах, у методичній літературі називають по-різному: синтетичним, загальним, суцільним, змішаним, комбінованим. Змішаний розбір - це характеристика слова, словосполучення або речення в двох і більше аспектах. Змішаним $\epsilon$, наприклад, морфологічно-синтаксичний, морфемно-словотворчий, лексико-морфологічний тощо. Цей розбір слід розглядати як підсумкову роботу і проводити в кінці і на початку року [8, с. 50-57].

Більш ефективним $є$ комбінований, або синтетичний, загальний, суцільний, наскрізний аналіз, який полягає в тому, що будь-яка мовна одиниця аналізується не в одному якомусь аспекті, наприклад, фонетичному, лексичному, а в кількох [1, с. 40]. Однак варто починати з розбору мовних явищ, пов'язаних із вивченням певних розділів курсу мови, у певній системі залежно від змісту матеріалу, мети і завдань уроку з поступовим переходом до мішаного розбору, що містить фонетичний, орфографічний, лексичний, синтаксичний та пунктуаційний різновиди тощо. Під час повторення й узагальнення доцільним є синтетичний розбір, що охоплює фонетику, лексику, граматику та стилістику. Тому ми дотримуємося думки тих методистів-педагогів (О. Біляєва, Г. Передрій, Л. Валентій, М. Чабайовської тощо), які виокремлюють види мовного розбору за характером виучуваного матеріалу (фонетичний, лексичний, слововірний, фразеологічний, морфемний, словотвірний і тощо) та за ступенем їх поєднання (мішаний, комбінований та синтетичний).

Ці визначення підкреслюють безпосередній характер мовного аналізу, зокрема, мовного розбору як складника будь-якого мовного аналізу, що є сукупністю методичних прийомів або методів, що систематично використовуються під час вивчення структури, типу мовних одиниць, їх форм і способів утворення, доцільність їх використання в тексті. Усі види мовного аналізу належать до активних методичних прийомів, що пов'язують теорію 3 практикою, забезпечують систематичне повторення i закріплення вивченого матеріалу [1, с. 40].

Не можна вважати мовний розбір механічним та схематичним засобом вивчення мови, оскільки він є певної мірою універсальним методом навчання, який не тільки закріплює набуті учнями знання, а й активізує їх пізнавальні можливості, зокрема, резервні. Він сприяє формуванню в них навичок послідовного, вдумливого аналізу мовних одиниць, привчає користуватися науковими прийомами аналізу й синтезу, допомагає в організації 
самостійної роботи.

На нашу думку, мовний розбір нині $є$ доцільним видом вправ узагальнення та систематизації набутих знань учнів з української мови, який потрібно ширше практикувати на уроках української мови не тільки в початкових класах, а й у середніх і старших, оскільки курс української мови передбачає постійне повторення усього вивченого за попередні роки. Ми дотримуємося думки педагогів про те, що мовний розбір може застосовуватися і на різних етапах засвоєння знань: під час опрацювання нової теми, закріплення, повторення матеріалу та з контрольною метою [10, с. 5].

Особливе місце у методичній літературі посіли проблеми мовного аналізу (розбору) нині. Учителі визнають необхідність проведення мовних аналізів, зокрема, комбінованих, які дозволяють виявити системні зв'язки між мовними одиницями (наприклад, морфемнолексичний аналіз підкреслює зв'язок між семантикою слова і значущими частинами, словотвірний аналіз неможливий без морфемного тощо). Проведення мовного аналізу, розбору у шкільній практиці залежить від того, як учитель сам володіє відповідною методикою, як він орієнтує на таку роботу учнів. Помилково вважати, що виконувати мовний розбір можна на якомусь певному етапі вивчення матеріалу, переважно для закріплення. Це ефективний прийом навчання, систематизації, закріплення, узагальнення знань. Безумовно, повний аналіз можна виконати після повного засвоєння мовного матеріалу (саме розбір допоможе виявити прогалини у знаннях). Наприклад, під час морфологічного розбору іменника учні повинні визначити і лексико-граматичні розряди цієї частини мови, $\mathrm{i}$ граматичні категорії роду, числа і відмінка, і морфемну будову слова, виконати словотвірний аналіз, зазначити орфографічні особливості, синтаксичну функцію слова в певному реченні. У цьому безпосередньо і виявляється компетентнісний підхід у вивченні того чи того мовного матеріалу.

Проте методиці мовного розбору в чинних підручниках 3 української мови, призначених для учнів початкових, середніх та старших класів, приділено недостатньо уваги. Подано схеми та зразки або не всіх видів розбору, або деякі схеми недостатньо повно охоплюють мовні явища, що вивчаються відповідно до навчальної програми. Тому є потреба в навчально-методичних посібниках, методичних матеріалах, що містять основні схеми та зразки мовних розборів, методичні зауваження та коментарі щодо порядку виконання розборів, що допоможе учням в оволодінні відповідним матеріалом, сприятиме узагальненню та систематизації набутих знань 3 української мови. I такі методичні рекомендації дедалі частіше трапляться в різних фахових виданнях. Однак треба критично ставитися до будь-якого методичного матеріалу, спираючись насамперед на фактичний матеріал. Наприклад, під час морфемного розбору дієслова у початковій формі (інфінітиві) донедавна виникали труднощі, оскільки в попередньому виданні підручника з рідної мови для 4 класу (частина друга) було подано правило про те, що неозначена форма дієслова $є$ незмінною і при цьому зазначалося, що кінцева частина $m и$, mь називається закінченнями $\mathrm{i}$ позначається, як змінна частина слова. У новому підручнику з української мови ці неточності виправлено.

До сьогодні трапляються помилки в методичних рекомендаціях щодо розбору слів за будовою (наприклад, у довіднику: Учися вчитися. - Тернопіль, 1998. - С. 24). Так, у слові весело виділяють суфікс $о$ та нульове закінчення, однак це слово є незмінним, тому у його будові не можна виокремлювати закінчення. У сучасних виданнях подібних огріхів стає дедалі менше, що зумовлено потребою саме в навчально-методичних посібниках, методичних матеріалах, що містять основні схеми та зразки мовних розборів з методичними 
зауваженнями та коментарями.

Отже, мовний розбір $є$ не тільки ефективним методом навчання, активним методичним прийомом, що сприяє розвиткові логічного мислення, кращому засвоєнню теоретичних відомостей із мови, формуванню мовних і мовленнєвих умінь та навичок, допомагає в оволодінні відповідним матеріалом під час організації самостійної роботи, а $є$ також доцільним засобом узагальнення та систематизації набутих знань учнів з української мови. Різні види мовного розбору сприяють роботі над формуванням загальномовної компетентності учнів, зокрема, початкових класів.

Учні середньої та старшої школи мають уявлення про різні види мовних розборів, оскільки з основами (елементами) їх вони ознайомилися саме у початковій школі. Учителеві необхідно організувати роботу над мовними розборами так, щоб діти усвідомили їх необхідність як засобу системності відповідних мовних одиниць та конструкцій. Однак, як засвідчує практика, учні, а також випускники загальноосвітніх середніх навчальних закладів недооцінюють важливість такої форми наукового представлення мовних одиниць, навчального матеріалу загалом.

Вивчення певного розділу з курсу мови необхідно супроводжувати аналізом мовних явищ у певній системі залежно від змісту матеріалу, мети і завдань уроку з поступовим переходом до мішаного розбору, що містить фонетичний, орфографічний, лексичний, стилістичний, синтаксичний та пунктуаційний різновиди тощо.

Більш ефективним $є$ комбінований, або синтетичний, загальний, суцільний, наскрізний аналіз, який полягає в тому, що будь-яка мовна одиниця аналізується не в одному аспекті, а в кількох.

У сучасних підрічниках часто міститься матеріал репродуктивного характеру, а мовний розбір $\epsilon$ тим універсальним методом навчання, який не тільки закріплює набуті учнями знання, а й активізує їх пізнавальні резервні можливості. Він сприяє формуванню в них навичок усвідомленого аналізу мовних одиниць, привчає користуватися науковими прийомами аналізу й синтезу, допомагає в організації самостійної роботи. Окрім цього, для виконання певних розборів діти працюють із різноманітними словниками (тлумачними, синонімів, антонімів, іншомовних слів тощо), що, зі свого боку, розширює світогляд учнів, поповнює їхній словниковий запас, розвиває чуття мови.

Елементи відповідного мовного аналізу слід упроваджувати в міру опрацювання програмового матеріалу, а повний - після вивчення (розділу) теми. Однак для формування стійких і свідомих навичок мовних аналізів та закріплення знань із програмового матеріалу необхідно проводити протягом вивчення усього курсу української мови, особливо для підготовки до підсумкової державної атестації та зовнішнього незалежного оцінювання.

\section{Література}

1. Валентій Л. В. Мовний аналіз як метод навчання в школі / Л. Валентій // Українська мова та література в школі. - 1996. - № 3. - С. 40-43. 2. Великий тлумачний словник сучасної української мови [укл. і голов. ред. В. Т. Бусел]. - Київ; Ірпінь : ВТФ «Перун», 2005. - 1728 с. 3. Ганич Д. І. Словник літературознавчих термінів / Д. І. Ганич, I. С. Олійник. - Київ : Головне вид-во видавничого об'єднання «Вища школа», 1985. - 360 с. 4. Дорошенко С. I. Методика викладання української мови: [навч. посіб.] / С. І. Дорошенко, М. С. Вашуленко, О. І. Мельничайко / За ред. С. І. Дорошенко. - Київ : Вища школа, 1992. 398 с. 5. Мельничайко В. Я. Види мовного розбору: [довідник] / В. Я. Мельничайко. Тернопіль : Богдан, 1997. - 120 с. 6. Методика навчання української мови в початковій школі: [навч. посіб.] / за наук. ред. М. С. Вашуленка. - Київ : Літера ЛТД, 2011. - 364 с. 
7. Навчальні програми для загальноосвітніх навчальних закладів із навчанням українською мовою. 1-4 класи. - Київ : Видавничий дім «Освіта», 2012. - С. 10-70. 8. Передрій Г. Р. Змішаний розбір як прийом повторення вивченого в 4 класі / Г. Р. Передрій // Українська мова і література в школі. - 1980. - № 3. - С. 12-16. 9. Розвиток життєвих компетентностей на уроках української мови / упоряд. Л. В. Бутрин. - Тернопіль-Харків : Ранок, 2011. - 144 с. 10. Чабайовська М. І. Мовний розбір у вищій та початковій школі: [навч.-мет. посіб.] / М. І. Чабайовська - Тернопіль : Мальва-ОСО, 2008. - 124 с.

УДК 37.013 .42

Валентина Костина

\section{ФОРМИРОВАНИЕ ОБРАЗОВАТЕЛЬНОГО ПРОСТРАНСТВА ПРОФЕССИОНАЛЬНОЙ ПОДГОТОВКИ БУДУЩИХ СОЦИАЛЬНЫХ ПЕДАГОГОВ К РАБОТЕ С ДЕЗАДАПТИРОВАННЫМИ ДЕТЬМИ И МОЛОДЕЖЬЮ}

Костіна В. В. Фурмування освітнього простору професійної підготовки майбутніх соціальних педагогів до роботи з дезадаптованими дітьми та молоддю.

У статті висвітлено зміст підготовки майбутніх соціальних педагогів до роботи 3 дезадаптованими дітьми та молоддю в умовах професійно спрямованого освітнього простору; окреслено особливості підготовки майбутніх соціальних педагогів в умовах організації роботи студентського наукового товариства; наведено результати експериментальних досліджень рівня професійної підготовки майбутніх соціальних педагогів до роботи з дезадаптованими дітьми та молоддю.

Ключові слова: соціальний педагог, дезадаптовані діти й молодь, освітній простір, професійна підготовка майбутніх соціальних педагогів.

Костина В. В. Формирование образовательного пространства профессиональной подготовки будущих социальных педагогов к работе с дезадаптированными детьми и молодежью. В статье раскрыто содержание подготовки будущих социальных педагогов к работе с дезадаптированными детьми и молодежью в условиях профессионально направленного образовательного пространства; определены особенности подготовки будущих социальных педагогов в условиях организации работы студенческого научного общества; приведены результаты экспериментальных исследований уровня профессиональной подготовки будущих социальных педагогов к работе с дезадаптированными детьми и молодежью.

Ключевые слова: социальный педагог, дезадаптированные дети и молодежь, образовательное пространство, профессиональная подготовка будущих социальных педагогов.

Kostina V. V. Formation of educational environment of future social teachers professional training to work with maladjusted children and youth.

In this article the training content of future social teachers to work with maladjusted children and youth in the conditions of professionally directed educational environmen has been dicussed; the features of future social teachers training under the organization of work of student's scientific society have been defined; the results of experimental research of the professional training level of future social teachers to work with maladjusted children and youth have been shown.

Key words: social teacher, maladjusted children and youth, educational environment, 